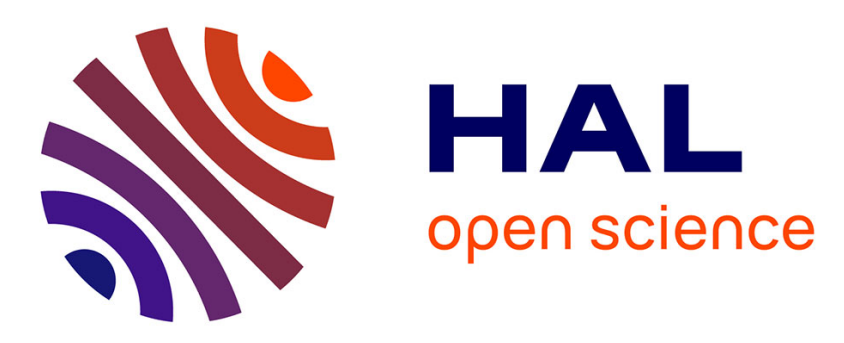

\title{
Facile Synthesis and High Rate Capability of Silicon Carbonitride/Boron Nitride Composite with a Sheet-Like Morphology
}

Lamuel David, Samuel Bernard, Christel Gervais, Philippe Miele, Gurpreet Singh

\section{To cite this version:}

Lamuel David, Samuel Bernard, Christel Gervais, Philippe Miele, Gurpreet Singh. Facile Synthesis and High Rate Capability of Silicon Carbonitride/Boron Nitride Composite with a Sheet-Like Morphology. Journal of Physical Chemistry C, 2015, 119 (5), pp.2783-2791. 10.1021/jp508075x . hal-01275034

\section{HAL Id: hal-01275034 \\ https://hal.science/hal-01275034}

Submitted on 3 Sep 2021

HAL is a multi-disciplinary open access archive for the deposit and dissemination of scientific research documents, whether they are published or not. The documents may come from teaching and research institutions in France or abroad, or from public or private research centers.
L'archive ouverte pluridisciplinaire HAL, est destinée au dépôt et à la diffusion de documents scientifiques de niveau recherche, publiés ou non, émanant des établissements d'enseignement et de recherche français ou étrangers, des laboratoires publics ou privés. 


\section{Facile Synthesis and High Rate Capability of Silicon}

\section{Carbonitride/Boron Nitride Composite with a Sheet-}

\section{Like Morphology}

Lamuel David ${ }^{1}$, Samuel Bernard ${ }^{2}$, Christel Gervais ${ }^{3}$, Philippe Miele ${ }^{2}$, and Gurpreet Singh $^{1 *}$ ${ }^{1}$ Mechanical and Nuclear Engineering Department, Kansas State University, Manhattan, Kansas, 66506-United States

${ }^{2}$ IEM (Institut Europeen des Membranes), UMR 5635 (CNRS-ENSCM-UM2), Universite Montpellier 2, Place E. Bataillon, F-34095, Montpellier, France

${ }^{3}$ Sorbonne Universités, UPMC Univ Paris 06, CNRS, Collège de France, UMR 7574, Chimie de la Matière Condensée de Paris, F-75005, Paris, France

*E-mail: gurpreet@ksu.EDU Tel.: +1-785-532-7085 Fax: +1-785-532-7057

\section{ABSTRACT}

We report synthesis of a sheet-like composite composed of hexagonal boron nitride (or $\mathrm{BN}$ ) chemically integrated with silicon carbonitride $(\mathrm{SiCN})$ matrix via a simple pyrolysis route. The composite offers several unique features such as improved electrical conductivity, hightemperature oxidation resistance (at $1000{ }^{\circ} \mathrm{C}$ ), and high electrochemical activity toward Li-ions generally not observed in $\mathrm{SiCN}$ or boron doped SiCN. Tested as electrode in Li-ion half-cell, $\mathrm{SiCN} / \mathrm{BN}$ show charge capacity of $\sim 517 \mathrm{mAh} \mathrm{g}^{-1}$ at $100 \mathrm{~mA} \mathrm{~g}^{-1}$ and $283 \mathrm{mAh} \mathrm{g}^{-1}$ at $2400 \mathrm{~mA} \mathrm{~g}^{-1}$ with respect to total weight of electrode. Additionally, a stable charge capacity of $\sim 401 \mathrm{mAh} \mathrm{g}^{-1}$ at $100 \mathrm{~mA} \mathrm{~g}^{-1}$ is retained even after continuous operation for 1000 cycles at $1600 \mathrm{~mA} \mathrm{~g}^{-1}$. Chemical characterization of the composite suggests that addition of BN to polysilazane in moderate amounts $(\sim 10 \mathrm{wt} \%)$ and subsequent pyrolysis resulted in an increased free-carbon 
content in the amorphous $\mathrm{SiCN}$ phase, which exceeded the percolation limit, leading to the improved electrical conductivity and Li-reversible capacity.

Keywords: graphene, nanosheets, polymer-derived ceramics, anode, lithium ion battery, 2-D materials.

\section{INTRODUCTION}

Powering of electric vehicles or next generation wearable electronic devices that run on Li-ion battery (LIB) technology will require new electrode materials beyond the traditional graphite anode because of its poor rate capability and low charge capacity (theoretical charge capacity approximately $\left.372 \mathrm{mAh} \mathrm{g}^{-1}\right){ }^{1-7}$ Desired characteristics of next-generation LIB system include high power and energy density, improved safety, long life, and lightweight. ${ }^{1-2,8}$ Research has shown that silicon $(\mathrm{Si})$ anodes can drastically increase the capacity of existing LIB by more than 30\%. ${ }^{9-11}$ Unfortunately, however, Si experiences huge volume changes during charge/discharge cycles and has poor electrical conductivity that generally leads to poor rate capability. ${ }^{12-13}$ Although, nanoengineered Si-based materials (such as nanowires, nanoparticles and hollow nano-spheres) that can sustain large mechanical strains with minimal capacity degradation have shown promise in laboratory experiments, a practical and cost-effective solution is yet to be realized. $^{14-26}$

Among other Si-based materials for LIB anodes, silicon-based polymer-derived ceramics (or PDCs) rich in carbon have shown high specific capacity even at high current densities. ${ }^{27-39}$ These ceramics are lightweight (density $\sim 1.8$ to $2.2 \mathrm{~g} \cdot \mathrm{cm}^{-3}$ ), chemically inert, stable at high temperatures, and readily synthesized through direct pyrolysis of single-source polymeric precursors. Two main types of PDCs, SiCO (silicon oxycarbide) and SiCN (silicon carbonitride), have gained attention because their Li discharge capacity is nearly 3 times the discharge capacity 
of commercial graphite anode..$^{28-30,32-38}$ This high capacity is derived from the particular structure of PDCs, which consists of a three-dimensional network of silicon, carbon and nitrogen (or oxygen for $\mathrm{SiCO}$ ) atoms and excess disordered carbon (or free carbon phase) that generally provides majority of active sites for reversible adsorption of lithium ions. ${ }^{34}$ However, cycling stability and efficiency of polysilazane-derived $\mathrm{SiCN}$ is considerably lower than SiCO anode. SiCN generally suffers from very high first cycle loss of $\mathrm{Li}$ (up to $70 \%$ in certain cases) ${ }^{29,31}$ and has low electrical conductivity that brings down its reversible capacity and rate capability to values similar or worse than commercial graphite after only a few initial cycles. ${ }^{35-36}$ Research has shown that some of these weaknesses can be addressed by changing the pyrolysis conditions (such as extended heat treatment), altering the polymeric precursor type (e.g., polysilylcarbodiimide is preferred over polysilazane) or, by introducing a suitable quaternary element, such as boron or aluminum, ${ }^{40-46}$ at molecular scale. In previous work, precursor-derived amorphous $\mathrm{Si}(\mathrm{B}) \mathrm{CN}$ ceramics showed improved electric property (up to 4 orders of magnitude higher conductivity than $\mathrm{SiCN}$ ) and superior electrochemical performance. ${ }^{46,}{ }^{47}$ In addition, composites made of SiCN matrix with filler phases comprised of carbon nanotubes (CNTs), ${ }^{48}$ graphite, ${ }^{49}$ and carbon nanofiber ${ }^{50}$ have been shown to improve electrical conductivity and resistance to mechanical cracking. However, rate capability and cycling stability of $\mathrm{Si}(\mathrm{B}) \mathrm{CN}$ and SiCN-based nanocomposite electrodes remain inferior to polymer-derived $\mathrm{SiCO}$ or other nanocomposite electrodes currently under investigation. One reason for this inferiority could be the presence of $\mathrm{Si}, \mathrm{C}, \mathrm{N}, \mathrm{O}$ danglings bonds which may form $\mathrm{Li}$ irreversible phases resulting in high first cycle loss. For precursor-derived $\mathrm{Si}(\mathrm{B}) \mathrm{CN}$, it could be the limited amounts of $\mathrm{B}$ that is ultimately retained in the pyrolyzed ceramic. Therefore, based on improved electrochemical performance of $\mathrm{Si}(\mathrm{B}) \mathrm{CN}$ ceramics compared to $\mathrm{SiCN}$ ceramics, we conclude that introduction of 
higher quantities of boron as (nano) sheets or (nano) particles in the SiCN network is a logical parallel step toward the improvement of electrochemical performance. Sheet or particle-like morphology is expected to improve overall accessibility for $\mathrm{Li}$ ions in the electrode during successive charge/discharge cycles.

We synthesized a SiCN/BN composite by functionalizing hexagonal boron nitride (h-BN, expressed here as $\mathrm{BN}$ ) sheets with a commercial off-the-shelf polysilazane precursor, followed by pyrolysis at $1000{ }^{\circ} \mathrm{C}$. We observed that preparation of SiCN/BN composite with a sheet-like morphology provided a unique opportunity to tailor the nitrogen bonds with boron and also increased free carbon content in the $\mathrm{SiCN}$ matrix, thereby, improving its electrical conductivity by orders of magnitude compared to boron-free SiCN ceramics. These changes in the molecular structure of the final ceramic yielded a material with excellent electrochemical stability even at high current densities. Composites made of SiCN matrix and precursor-derived BN (SiCN/BNF) and powdered boron $(\mathrm{SiCN} / \mathrm{BP})$ as filler phase were also prepared in order to extrapolate and highlight the distinctive chemistry that governs high capacity in SiCN/BN.

\section{MATERIALS AND INSTRUMENTATION}

Boron nitride (99.9\%) was purchased from Sigma Aldrich. Poly (ureamethylvinyl)silazane (commercial name: Ceraset) was obtained from Clariant Corporation. All materials were used as received without further purification.

Scanning electron microscopy (SEM) of the synthesized material was carried out on a Carl Zeiss EVO MA10 system with incident voltage of $5 \mathrm{kV}-30 \mathrm{kV}$. Transmission electron microscopy (TEM) images were digitally acquired by use of a Phillips CM100 operated at $100 \mathrm{kV}$. Surface chemical composition was studied by X-ray photoelectron spectroscopy (XPS, PHI Quantera 
$\mathrm{SXM})$ using monochromatic $\mathrm{Al} \mathrm{K} \alpha \mathrm{X}$-ray radiation. ${ }^{11} \mathrm{~B}$ MAS NMR spectra were recorded at 11.7 T on a Bruker Avance500 wide-bore spectrometer operating at $160.47 \mathrm{MHz}$, using a Bruker $4 \mathrm{~mm}$ probe and a spinning frequency of the rotor of $12 \mathrm{kHz}$. Spectra were acquired using a spinecho $\theta$-t- $2 \theta$ pulse sequence with $\theta=90^{\circ}$ to overcome problems of probe signal. The $\mathrm{t}$ delay ( 83 $\mu \mathrm{s})$ was synchronized with the spinning frequency and recycle delay of $1 \mathrm{~s}$ was used. Chemical shifts were referenced to $\mathrm{BF}_{3}(\mathrm{OEt})_{2}(\delta=0 \mathrm{ppm})$. The FTIR spectra were collected using ThermoNicolet Nexus 870FT-IR spectrometer. FTIR samples were prepared by mixing $\sim 1 \mathrm{wt} \%$ of the finely powdered sample with FTIR grade $\mathrm{KBr}$ powder. Phase evolution was characterized by using Bruker powder X-ray diffractometer (Madison, WI) operating at room temperature, with $\mathrm{CuK} \alpha$ radiation and nickel filter. The pyrolyzed samples were finely crushed with mortar and pestle and laid on the palette for analysis. Thermogravimetric analysis was performed using Shimadzu 50 TGA (Columbia, MD) (limited to $1000^{\circ} \mathrm{C}$ ). Sample weighing, $2.5 \mathrm{mg}$, was heated in a platinum pan at a rate of $10{ }^{\circ} \mathrm{C} \mathrm{min}^{-1}$ in air flowing at $10 \mathrm{~mL} \mathrm{~min}$.

\section{PREPARATION OF SiCN/BN, SiCN/BNF, SiCN/BP}

SiCN/BN: Chemical modification of Polyureasilazane (commercial name: Ceraset) was performed using commercially obtained BN (99.9\%) nanosheets from Sigma Aldrich ${ }^{\mathrm{TM}} \cdot 1 \mathrm{~g}$ of $\mathrm{BN}$ (sonicated in propanol and dried) was mixed with $10 \mathrm{~mL}$ of polyureasilazane and stirred for $12 \mathrm{~h}$ at room temperature. Subsequently the mixture was cross-linked at $250{ }^{\circ} \mathrm{C}$ (heating rate 100 ${ }^{\circ} \mathrm{C} \mathrm{h}^{-1}$ ) for 180 min to obtain a white powder. The cross-linked powder was then pyrolyzed in $\mathrm{N}_{2}$ atmospheres at $1000{ }^{\circ} \mathrm{C}$ in a tube furnace to obtain an amorphous black powder termed as $\mathrm{SiCN} / \mathrm{BN}$ 
SiCN/BNF and SiCN/BP specimens: Similar procedure was followed as conducted for SiCN/BN preparation with the exception that instead of commercially obtained $\mathrm{BN}$, the following boron modifiers were added to polyureasilazane: cross-linked $\mathrm{BN}$ polymeric precursor synthesized using procedure from literature ${ }^{51-57}$ for synthesizing SiCN/BNF and commercially obtained boron powder from Sigma Aldrich for SiCN/BP.

\section{PREPARATION OF PAPER ELECTRODE}

$10 \mathrm{~mL}$ colloidal suspension of GO (graphene oxide) in 1:1 (v/v) water was made by sonication for 10 minutes. GO was synthesized using Hummer's method. ${ }^{58} 60$ wt $\%$ active material ( $\mathrm{SiCN} / \mathrm{BN}, \mathrm{SiCN} / \mathrm{BNF}$ or $\mathrm{SiCN} / \mathrm{BP}$ ) in $10 \mathrm{~mL}$ of isopropanol (ISP) was added to this solution and the solution was further sonicated for $60 \mathrm{~min}$. When creation of the composite suspension was complete, it was filtered by vacuum filtration through a $10 \mu \mathrm{m}$ filter membrane. Composite paper was carefully removed from the filter paper and dried. This dry paper then underwent reduction by heat treatment in a tube furnace at $500{ }^{\circ} \mathrm{C}$ under flowing argon gas for $2 \mathrm{~h}$. The thermal reduction process resulted in conversion of GO to rGO (reduced graphene oxide) with approximately $50-60 \%$ weight loss. The thermally reduced composite papers consisted of approximately $20 \mathrm{wt} \%$ rGO.

\section{COIN CELL ASSEMBLY}

Half-cell batteries were made by punching a $14.3 \mathrm{~mm}$ diameter circle from the paper for use as working electrode. A few drops of electrolyte solution of $1 \mathrm{M} \mathrm{LiPF}_{6}\left(\mathrm{Alfa}_{\mathrm{Aesar}}^{\mathrm{TM}}\right)$ dissolved in $(1: 1 \mathrm{v} / \mathrm{v})$ dimethyl carbonate: ethylene carbonate (ionic conductivity $\left.10.7 \mathrm{mS} \mathrm{cm}^{-1}\right)$ was used. A $19 \mathrm{~mm}$ diameter glass separator soaked in electrolyte was placed between the working electrode and pure lithium metal (14.3 mm diameter), which acted as a counter electrode. Washer, spring, 
and a top casing were placed on top to complete the assembly before crimping. The entire procedure was conducted out in an Ar-filled glovebox.

Electrochemical performance of assembled coin cells was tested using a multichannel BT2000 Arbin ${ }^{\mathrm{TM}}$ test unit sweeping $2.5 \mathrm{~V}$ to $10 \mathrm{mV}$ versus $\mathrm{Li} / \mathrm{Li}^{+}$using the following cycle schedule: (a) Asymmetric mode: $\mathrm{Li}$ was inserted at $0.1 \mathrm{~A} \mathrm{~g}^{-1}$ (with respect to total electrode weight), while the extraction was performed at increasing current densities of 100, 200, 400, 800, 1600 and 2400 $\mathrm{mA}^{-1}$ for five cycles each, and returning to $100 \mathrm{~mA} \mathrm{~g}^{-1}$ for the subsequent 10 cycles. (b) Symmetric mode: Later, all the cells were subjected to symmetric cycling at a current density of $1600 \mathrm{~mA} \mathrm{~g}^{-1}$ for up to 1000 cycles, returning to $100 \mathrm{~mA} \mathrm{~g}^{-1}$ for the last 20 cycles.

\section{RESULTS AND DISCUSSIONS}

The schematic in Figure 1 describes the possible reaction mechanism involved in the formation of $\mathrm{SiCN} / \mathrm{BN}$ composite. We hypothesize that vigorous physical mixing of few-layer thick boron nitride $(\mathrm{BN})$ sheets with liquid polysilazane results in their chemical functionalization, which, upon cross-linking at $300{ }^{\circ} \mathrm{C}$, forms polysilazane/BN polymer composite. With additional heating in $\mathrm{N}_{2}$ at $1000{ }^{\circ} \mathrm{C}$, polysilazane transforms to $\mathrm{SiCN}$ with evolution of $\mathrm{H}_{2}, \mathrm{CH}_{4}$, and $\mathrm{NH}_{3}$ forming an integrated $\mathrm{SiCN} / \mathrm{BN}$ composite with a layered morphology.

Electron microscopy images of as-obtained BN powder and as-synthesized SiCN/BN composite are compared in Figure 2 and Supporting Information Figure S1. TEM and SEM images confirmed a layered and 'fluffy' structure of the as-obtained BN, while SiCN/BN composite appeared more dense and compact, although sheet-like morphology of initial BN could still be observed. The selected area electron diffraction (SAED) pattern for SiCN/BN was similar to BN, indicating that $\mathrm{BN}$ sheets were intact in the composite. From the SEM images, the average 
particle size of SiCN/BN was observed to be approximately (5 to 10) $\mu \mathrm{m}$. As-pyrolyzed SiCN and $\mathrm{SiCN}$ modified with boron particles (i.e., SiCN/BP) and cross-linked polyborazylene (i.e., $\mathrm{SiCN} / \mathrm{BNF}$ ) appeared more irregular with tiny particles decorating big micrometer size particles, as shown in Supporting Information Figure S1(a through e) in a side-by-side comparison.

Top-view and cross-section SEM images of various paper electrodes prepared with rGO (reduced graphene oxide) as conducting support (see Methods section for electrode preparation) are presented in Supporting Information Figure S1 (f through o); the free-standing paper electrode with rGO support had a thickness of approximately 20 to $25 \mu \mathrm{m}$. Closer examination showed the paper to be layered with rGO platelets embedded with SiCN/BN particles which had sheet-like morphology.

Further characterization involved X-ray photoelectron spectroscopy (XPS) analysis of SiCN/BN composite as shown in Figure 3(a-b), which revealed distinct peaks from which elemental composition of the final material was confirmed. Survey scans in Supporting Information Figure $\mathrm{S} 2$ of $\mathrm{SiCN} / \mathrm{BN}$ showed the existence of $\mathrm{Si}, \mathrm{B}, \mathrm{N}$ and $\mathrm{C}$ elemental peaks rising from valence energy levels for the respective atoms. Atomic percentage of boron in the composite was $6.8 \%$, which is much higher than other boron-doped $\mathrm{SiCN} .{ }^{40}$ The peak at approximately $190.5 \mathrm{eV}$ for high resolution $\mathrm{B} 1 \mathrm{~s}$ in Figure $3 \mathrm{~b}$ confirmed the presence of $\mathrm{B}-\mathrm{N}$ bond in the pyrolyzed composite, thereby suggesting successful retention of $\mathrm{BN}$ after pyrolysis. ${ }^{40,}{ }^{42}$ High resolution XPS spectrum of C 1s and N 1s for $\mathrm{SiCN}$ and $\mathrm{SiCN} / \mathrm{BP}$ are included in Supporting Information Figure $\mathrm{S} 3$. A comparison of $\mathrm{C}$ 1s peaks with $\mathrm{SiCN} / \mathrm{BN}$ revealed that three distinct peaks could be fitted at 283.4, 284.5, and $288 \mathrm{eV}$ attributed to $\mathrm{Si}-\mathrm{C}, \mathrm{C}-\mathrm{C}$, and $\mathrm{C}-\mathrm{O}$ bonds, respectively. Closer examination of the area under the peaks revealed a higher percentage of $\mathrm{C}-\mathrm{C}$ bonds $\left(-\mathrm{sp}^{2}\right.$ type carbon) in $\mathrm{SiCN} / \mathrm{BN}(0.14 \%)$ compared to 'neat' $\mathrm{SiCN}(0.04 \%)$ and $\mathrm{SiCN} / \mathrm{BP}(0.1 \%)$ 
specimens. The N 1s spectrum for SiCN/BN specimen could be resolved to Si-N (396.8 eV) and B-N (398.2 eV) while the spectrum for SiCN and SiCN/BP specimens were similar and resolved to two Si-N bonds at (396.8 and $397.1 \mathrm{eV})$. High-resolution B 1s spectrum (Supporting Information Figure S4) of SiCN/BNF was quite different with an emergence of a weak peak at $192.2 \mathrm{eV}$. That peak was the only observable peak in SiCN/BP.

The chemical bonds present were also characterized using Fourier Transform Infrared (FTIR) spectroscopy which showed that $\mathrm{SiCN} / \mathrm{BN}$ and $\mathrm{SiCN} / \mathrm{BNF}$ had strong BN bond vibrations with no obvious presence of B-O bonding (Supporting Information Figure S5). Peaks ascribed to vinyl groups are $\mathrm{C}-\mathrm{H}$ vibrations at $3047 \mathrm{~cm}^{-1}$ and $\mathrm{C}-\mathrm{C}$ stretching at $1591 \mathrm{~cm}^{-1}$. Peaks attributed to Si-NH-Si groups are $\mathrm{N}-\mathrm{H}$ stretching at $3374 \mathrm{~cm}^{-1}$ and $\mathrm{Si}-\mathrm{N}$ vibration at $1160 \mathrm{~cm}^{-1} \cdot \mathrm{Si}-\mathrm{CH}_{3}$ characteristic peaks are at $1253 \mathrm{~cm}^{-1}$ and methyl vibrations at 2954 and $2896 \mathrm{~cm}^{-1}$. The large peak at $2111 \mathrm{~cm}^{-1}$ is attributed to $\mathrm{Si}-\mathrm{H}$ and small peaks at 805 and $750 \mathrm{~cm}^{-1}$ can be assigned to $\mathrm{Si}-$ $\mathrm{N}$ and Si-C, respectively. ${ }^{59-63}$

Additional characterization of the composite was carried out by use of solid-state NMR $\left({ }^{11} \mathrm{~B}\right)$, as shown in Figure 3c. ${ }^{11} \mathrm{~B}$ solid-state MAS NMR spectra of samples SiCN/BN and SiCN/BNF demonstrated a main signal in the region of tricoordinated boron atoms tentatively simulated with a site at $30 \mathrm{ppm}(\mathrm{CQ}=3.0 \mathrm{MHz}, \eta=0.2)$ assigned to $\mathrm{B}-\mathrm{N}$ bonds in planar $\mathrm{BN}_{3}$ groups within $\mathrm{BN}$ graphitic layers. A second small signal at $\delta_{\text {iso }}=0.6 \mathrm{ppm}$ (no quadrupolar shape) is indicative of the presence of tetragonal $\mathrm{BO}_{4}$ groups in minor quantity. ${ }^{54,55}$ The ${ }^{11} \mathrm{~B}$ spectrum of $\mathrm{SiCN} / \mathrm{BP}$ showed a shapeless signal centered at $4.5 \mathrm{ppm}$ characteristic of amorphous elemental boron. $^{64}$ Chemical characterization of the hybrid matrix involved X-ray diffraction (XRD) to identify crystallinity of the composite material, as shown in Figure 3d. SiCN/BN spectrum was comparable to XRD of as-obtained BN powder spectrum (insert in Figure 3d) with characteristic 
002 peak at $28^{\circ} 2 \theta$, indicating that $\mathrm{BN}$ sheets were primarily intact in the amorphous $\mathrm{SiCN}$ ceramic matrix. Very weak but similar spectrum was obtained for SiCN/BNF specimen, while SiCN/BP material was featureless in X-ray.

In summary, FTIR and XPS characterization of SiCN/BN composite material suggested the presence of only $\mathrm{B}-\mathrm{N}$ bonding with little or no evidence of damage to $\mathrm{BN}$ sheets upon pyrolysis. ${ }^{42}$ While NMR data showed that the boron was tricoordinated as planar $\mathrm{BN}_{3}$ groups. Amorphous nature of $\mathrm{Si}-\mathrm{C}$ and $\mathrm{Si}-\mathrm{N}$ groups and crystalline B-N groups were observed using $\mathrm{XRD}$ in $\mathrm{SiCN} / \mathrm{BN}$ composite material. Results confirmed the structure deduced in Figure 1.

Thermogravimetric analysis (TGA) plots of all materials were compared (see Figure 3e) in order to identify thermal stability. SiCN/BN was extremely stable with no significant weight change even when heated to $1000{ }^{\circ} \mathrm{C}$ in flowing air. In contrast, SiCN/BNF composite showed a weight loss attributed to the presence of residual compounds (such as $\mathrm{H}_{2} \mathrm{O}$ ) in polyborazylene-derived BN (BNF) material. SiCN/BP composites had slight weight gain caused by oxidation of boron into boron oxide.

Four-point surface electrical conductivity of various ceramic specimens was also measured and compared. Data presented in Figure 3f clearly shows that SiCN/BN displayed highest electrical

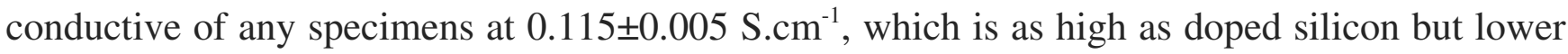
than the rGO. SiCN/BP demonstrated the next highest electrical conductivity. Increased conductivity of SiCN/BN composite (compared to other PDCs pyrolyzed under similar conditions) ${ }^{46,47}$ is attributed to the increased amounts of C-C bonding character in the composite, which was considerably higher as confirmed by the XPS. 
Electrochemical behavior of the $\mathrm{SiCN} / \mathrm{BN} / \mathrm{rGO}$ electrode (with approximately $20 \mathrm{wt}$ \% $\mathrm{rGO}$ as mechanical support) was studied by cycling it in a half-cell configuration against pure lithium metal. Mass loading of SiCN/BN in the composite paper was confirmed by use of TGA (see Supporting Information Figure S6). Specific capacity values were calculated with respect to total weight of the electrode and mass of active material. Figures $4 a$ and $4 b$ show the charge/discharge profile and differential capacity curves of the SiCN/BN electrode's first two cycles. First cycle discharge and charge capacities were observed to be 891 and $517 \mathrm{mAh} \mathrm{g}^{-1}$ with a first cycle loss of $58 \%$ at current density of $100 \mathrm{~mA} \mathrm{~g}^{-1}$. This capacity value is one of the highest reported for polysilazane-based anode materials. ${ }^{34-38}$ For example, first reversible capacity of SiCN/BN hybrid composite is better than $\mathrm{SiCN}$ annealed at $1000{ }^{\circ} \mathrm{C}\left(456 \mathrm{mAh} \mathrm{g}^{-1}\right),{ }^{36} \mathrm{C}$-rich $\mathrm{SiCN}(\sim 263$ mAh g $\left.{ }^{-1}\right),{ }^{37} \mathrm{SiCN}-1300{ }^{\circ} \mathrm{C}\left(383 \mathrm{mAh} \mathrm{g}^{-1}\right),{ }^{38} \mathrm{~B}$-doped SiCN $\left(\sim 100 \mathrm{mAh} \mathrm{g}^{-1}\right){ }^{47}$ and SiCN/graphite $\left(\sim 474 \mathrm{mAh} \mathrm{g}^{-1}\right){ }^{49}$ The differential capacity curve showed first cycle lithiation peaks at $50 \mathrm{mV}$, $150 \mathrm{mV}$, a weak plateau at $\sim 700 \mathrm{mV}$, and a delithiation plateau at $\sim 500 \mathrm{mV}$. From literature, the peak at $50 \mathrm{mV}$ could be attributed to $\mathrm{Li}$ intercalation/adsorption in graphitic carbon ${ }^{32,34}$ and the peak at $150 \mathrm{mV}$ corresponds to interaction of $\mathrm{Li}$ in nanovoids or interaction with dangling bonds present at $\mathrm{Si}$ and $\mathrm{C}$ sites in the ceramic. ${ }^{32,37,47}$ The plateau at $\sim 700$ to $800 \mathrm{mV}$, present only in the first cycle, originated due to formation of passive solid electrolyte interface (SEI) on graphite. This plateau was common to all electrodes including 'neat' rGO electrode and data from the literature (see Supporting Information Figure S7 for voltage profiles of BP/rGO, and BN/rGO electrodes). The charge/discharge profile and corresponding differential capacity curves of $\mathrm{SiCN} / \mathrm{BNF} / \mathrm{rGO}$ and $\mathrm{SiCN} / \mathrm{BP} / \mathrm{rGO}$ paper electrodes are shown in Supporting Information Figure S8. Lithiation peaks were at $50 \mathrm{mV}$ and $\sim 600 \mathrm{mV}$ with a corresponding delithiation peak at 200 $\mathrm{mV}$ (similar to $\mathrm{BN} / \mathrm{rGO}$ and $\mathrm{BP} / \mathrm{rGO}$ differential capacity curves). From these results we deduce 
that the capacity in $\mathrm{SiCN} / \mathrm{BN}$ originates primarily from $\mathrm{BN}$ enhanced $\mathrm{SiCN}$-based $\mathrm{Li}$ intercalation sites while it is not the same in other ceramics that we tested. This is even more evident from the first cycle discharge capacities which were at $\sim 531 \mathrm{mAh} \mathrm{g}^{-1}$ and $347 \mathrm{mAh} \mathrm{g}^{-1}$ for $\mathrm{SiCN} / \mathrm{BNF} / \mathrm{rGO}$ and $\mathrm{SiCN} / \mathrm{BP} / \mathrm{rGO}$, respectively. Lower capacity values were observed in subsequent cycles because $\mathrm{BN}$ and boron particles have zero or negligible Li cyclability.

With additional cycling (Figure 4c), SiCN/BN/rGO maintained high capacity at $474 \mathrm{mAh} \mathrm{g}^{-1}$ (96\% of initial capacity retained) which is higher than $\mathrm{BN} / \mathrm{rGO}$ and $\mathrm{SiCN} / \mathrm{rGO}$ with charge capacities of 67 and $154 \mathrm{mAh} \mathrm{g}^{-1}$, respectively, after 5 cycles at $100 \mathrm{~mA} \mathrm{~g}^{-1}$. Current density was gradually increased to $200,400,800,1600$ and $2400 \mathrm{~mA} \mathrm{~g}^{-1}$ for each five cycles consecutively. Importantly, $\mathrm{SiCN} / \mathrm{BN} / \mathrm{rGO}$ hybrid composite maintained its reversible capacity of $283 \mathrm{mAh} \mathrm{g}^{-1}$ even at $2400 \mathrm{~mA} \mathrm{~g}^{-1}$. This capacity was $52 \%$ of the initial capacity. When the cells were cycled back at $100 \mathrm{~mA} \mathrm{~g}^{-1}$, all electrodes regained initial charge capacities at 449, 60, and $154 \mathrm{mAh} \mathrm{g}^{-1}$ for $\mathrm{SiCN} / \mathrm{BN} / \mathrm{rGO}, \mathrm{BN} / \mathrm{rGO}$, and $\mathrm{SiCN} / \mathrm{rGO}$, respectively. However, SiCN/BNF/rGO, $\mathrm{SiCN} / \mathrm{BP} / \mathrm{rGO}$, and BP/rGO performances, shown in Supporting Information Figure S9, were lower than $\mathrm{SiCN} / \mathrm{BN} / \mathrm{rGO}$. In order to test cell performance during long-term cycling, cells were cycled at $1600 \mathrm{~mA} \mathrm{~g}^{-1}$ during charge and discharge half cycles (see Figure 4d). SiCN/BN/rGO demonstrated stable and high charge capacity of $\sim 62 \mathrm{mAh} \cdot \mathrm{g}^{-1}$ than $\mathrm{BN} / \mathrm{rGO}$ and $\mathrm{SiCN} / \mathrm{rGO}$ anode at $\sim 25$ and $40 \mathrm{mAh} \mathrm{g}^{-1}$, respectively. All electrodes regained most of initial capacity when they were cycled at $100 \mathrm{~mA} \mathrm{~g}^{-1}$ after 1000 cycles. SiCN/BN/rGO was the best performing anode with a charge capacity of $401 \mathrm{mAh} \mathrm{g}^{-1}$ at $100 \mathrm{~mA} \mathrm{~g}^{-1}$ even after symmetric cycling at $1600 \mathrm{~mA}$ $\mathrm{g}^{-1}$ for 1000 cycles. Summary of the electrochemical data and comparison with recent literature (including graphite ${ }^{65}$ and rGO paper electrode ${ }^{66}$ ) is presented in Table 1. Further, Galvanostatic Intermittent Titration Technique (GITT) was performed to obtain the solid state Li-ion diffusion 
coefficient $\left(\mathrm{D}_{\mathrm{Li}+}\right)$ of $\mathrm{SiCN} / \mathrm{BN}$ electrode (Supporting Figure $\mathrm{S} 10$ ). The acquired $\mathrm{D}_{\mathrm{Li}+}$ varied between approximately $\left(10^{-10}\right.$ to $\left.1.4 \times 10^{-12}\right) \mathrm{cm}^{2} \cdot \mathrm{s}^{-1}$ and $\left(3.9 \times 10^{-10}\right.$ to $\left.2.6 \times 10^{-11}\right) \mathrm{cm}^{2} \cdot \mathrm{s}^{-1}$ during the insertion and extraction half, respectively. These values are comparable to SiBCN-CNT ( $10^{-9}$ to $\left.10^{-12} \mathrm{~cm}^{2} . \mathrm{s}^{-1}\right)^{47}$ electrodes but lower than the chemical diffusivity of Li-ion in graphite. ${ }^{67-68}$

High charge capacity of $\mathrm{SiCN} / \mathrm{BN}$ is attributed to the three-fold advantage associated with the addition of boron to $\mathrm{SiCN}$ matrix in the form of $\mathrm{BN}$ sheets: (1) possible neutralization of nitrogen atoms by boron. SiCN electrodes with higher nitrogen content typically demonstrates lower electrochemical performance, therefore, increased concentration of boron in $\mathrm{SiCN}$ neutralized some of the nitrogen dangling bonds in SiCN during pyrolysis, (2) sheet-like morphology, and (3) significant enhancement in electrical conductivity originating from increased $\mathrm{C}-\mathrm{C}$ bonds of the SiCN/BN hybrid ceramic matrix compared to other PDC material pyrolyzed under similar conditions. ${ }^{47}$

\section{CONCLUSION}

Synthesis of a chemically integrated SiCN/BN layered composite is demonstrated for the first time. The composite shows electrical conductivity similar to conductivity of doped-silicon, which is several orders of magnitude higher than that of 'neat' SiCN prepared under similar conditions. Additionally, unlike its individual constituents, the SiCN/BN composite offers high electrochemical activity and stability toward lithium-ions with charge capacity reaching $\sim 517$ $\mathrm{mAh} \mathrm{g}^{-1}$ at $100 \mathrm{~mA} \mathrm{~g}^{-1}$ and $\sim 283 \mathrm{mAh} \mathrm{g}^{-1}$ at $2400 \mathrm{~mA} \mathrm{~g}^{-1}$ with respect to total electrode weight. This behavior is attributed to the increased amount of $-\mathrm{sp}^{2}$ carbon in SiCN phase (observed only in presence of $\mathrm{BN}$ ) that may have exceeded its percolation limit and provided necessary sites for reversible lithium adsorption. Facile synthesis and improved thermal, electrical and 
electrochemical performance of $\mathrm{SiCN} / \mathrm{BN}$ composite is expected to open new applications for PDCs and 2-D nanomaterial hybrids.

\section{ACKNOWLEDGEMENTS}

This research is based on work supported by the National Science Foundation-Chemical, Bioengineering, Environmental, and Transport Systems Division (CBET) under grant no. 1335862 to G. Singh. L.D. Thanks former student Romil and Uriel for assistance with sample preparation. G. Singh thanks Professor G. Sorarù (University of Trento) and Dr. Yigal Blum (SRI International) for their useful insights.

\section{SUPPORTING INFORMATION}

SEM, TEM images and electrochemistry data corresponding to SiCN/BN, SiCN/BNF, SiCN/BP ceramic particles and 'neat' BN, BP. GITT data for SiCN/BN electrode. Electrical conductivity data. High resolution XPS C 1s and N 1s spectrum of SiCN, SiCN/BN and SiCN/BP. This information is available free of charge via the Internet at http://pubs.acs.org

\section{REFERENCES}

1. Armand, M.; Tarascon, J. M., Building Better Batteries. Nature 2008, 451, 652-657.

2. Tarascon, J. M.; Armand, M., Issues and Challenges Facing Rechargeable Lithium Batteries. Nature 2001, 414, 359-367.

3. Goodenough, J. B.; Kim, Y., Challenges for Rechargeable Li Batteries. Chem. Mater. 2010, 22, 587-603.

4. Arico, A. S.; Bruce, P.; Scrosati, B.; Tarascon, J. M.; Van Schalkwijk, W., Nanostructured Materials for Advanced Energy Conversion and Storage Devices. Nat. Mater. 2005, 4, 366-377. 
5. Choi, N. S.; Chen, Z.; Freunberger, S. A.; Ji, X.; Sun, Y. K.; Amine, K.; Yushin, G.; Nazar, L. F.; Cho, J.; Bruce, P. G., Challenges Facing Lithium Batteries and Electrical Double-Layer Capacitors. Angew. Chem., Int. Ed. 2012, 51, 9994-10024.

6. David, L.; Bhandavat, R.; Kulkarni, G.; Pahwa, S.; Zhong, Z.; Singh, G. Synthesis of Graphene Films by Rapid Heating and Quenching at Ambient Pressures and Their Electrochemical Characterization. ACS Appl. Mater. Interfaces 2013, 5, 546-552.

7. Manthiram, A., Materials Challenges and Opportunities of Lithium Ion Batteries. J. Phys. Chem. Lett. 2011, 2, 176-184.

8. Hu, L.; Xu, K., Nonflammable Electrolyte Enhances Battery Safety. Proc. Natl. Acad. Sci. U.S.A. 2014, 111, 3205-3206.

9. Park, C. M.; Kim, J. H.; Kim, H.; Sohn, H. J., Li-Alloy Based Anode Materials for Li Secondary Batteries. Chem. Soc. Rev. 2010, 39, 3115-3141.

10. Zhang, W. J., A Review of the Electrochemical Performance of Alloy Anodes for Lithium-Ion Batteries. J. Power Sources 2011, 196, 13-24.

11. Wu, H.; Cui, Y., Designing Nanostructured Si Anodes for High Energy Lithium Ion Batteries. Nano Today 2012, 7, 414-429.

12. Beaulieu, L. Y.; Eberman, K. W.; Turner, R. L.; Krause, L. J.; Dahn, J. R., Colossal Reversible Volume Changes in Lithium Alloys. Electrochem. Solid-State Lett. 2001, 4, A137-A140.

13. Nadimpalli, S. P. V.; Sethuraman, V. A.; Dalavi, S.; Lucht, B.; Chon, M. J.; Shenoy, V. B.; Guduru, P. R., Quantifying Capacity Loss Due to Solid-Electrolyte-Interphase Layer Formation on Silicon Negative Electrodes in Lithium-Ion Batteries. J. Power Sources 2012, 215, 145-151.

14. Park, M. H.; Kim, M. G.; Joo, J.; Kim, K.; Kim, J.; Ahn, S.; Cui, Y.; Cho, J., Silicon Nanotube Battery Anodes. Nano Lett. 2009, 9, 3844-3847.

15. Song, T.; Xia, J.; Lee, J. H.; Lee, D. H.; Kwon, M.-S.; Choi, J.-M.; Wu, J.; Doo, S. K.; Chang, H.; Il Park, W. et al. , Arrays of Sealed Silicon Nanotubes as Anodes for Lithium Ion Batteries. Nano Lett. 2010, 10, 1710-1716.

16. Kasavajjula, U.; Wang, C.; Appleby, A. J., Nano- and Bulk-Silicon-Based Insertion Anodes for Lithium-Ion Secondary Cells. J. Power Sources 2007, 163, 1003-1039. 
17. Liu, B.; Soares, P.; Checkles, C.; Zhao, Y.; Yu, G., Three-Dimensional Hierarchical Ternary Nanostructures for High-Performance Li-Ion Battery Anodes. Nano Lett. 2013, 13, 3414-3419.

18. Ruvinskiy, P.; Barsukov, I. V.; Mashtalir, O.; Reid, C. M.; Wu, J. J.; Gogotsi, Y., NanoSilicon Containing Composite Graphitic Anodes with Improved Cycling Stability for Application in High Energy Lithium-Ion Batteries. ECS J. Solid State Sci. Tech. 2013, 2, M3028-M3033.

19. McDowell, M. T.; Lee, S. W.; Nix, W. D.; Cui, Y., 25th Anniversary Article: Understanding the Lithiation of Silicon and Other Alloying Anodes for Lithium-Ion Batteries. Adv. Mater. 2013, 25, 4966-4984.

20. Kim, H.; Seo, M.; Park, M. H.; Cho, J., A Critical Size of Silicon Nano-Anodes for Lithium Rechargeable Batteries. Angew. Chem. Int. Ed. 2010, 49, 2146-2149.

21. Chockla, A. M.; Klavetter, K. C.; Mullins, C. B.; Korgel, B. A., Tin-Seeded Silicon Nanowires for High Capacity Li-Ion Batteries. Chem. Mater. 2012, 24, 3738-3745.

22. Chan, C. K.; Patel, R. N.; O'Connell, M. J.; Korgel, B. A.; Cui, Y., Solution-Grown Silicon Nanowires for Lithium-Ion Battery Anodes. ACS Nano 2010, 4, 1443-1450.

23. Deshpande, R.; Cheng, Y. T.; Verbrugge, M. W., Modeling Diffusion-Induced Stress in Nanowire Electrode Structures. J. Power Sources 2010, 195, 5081-5088.

24. Chockla, A. M.; Panthani, M. G.; Holmberg, V. C.; Hessel, C. M.; Reid, D. K.; Bogart, T. D.; Harris, J. T.; Mullins, C. B.; Korgel, B. A., Electrochemical Lithiation of Graphene-Supported Silicon and Germanium for Rechargeable Batteries. J. Phys. Chem. C 2012, 116, 11917-11923.

25. Ruffo, R.; Hong, S. S.; Chan, C. K.; Huggins, R. A.; Cui, Y., Impedance Analysis of Silicon Nanowire Lithium Ion Battery Anodes. J. Phys. Chem. C 2009, 113, 1139011398.

26. Luo, J.; Zhao, X.; Wu, J.; Jang, H. D.; Kung, H. H.; Huang, J., Crumpled GrapheneEncapsulated Si Nanoparticles for Lithium Ion Battery Anodes. J. Phys. Chem. Lett. 2012, 3, 1824-1829.

27. Fukui, H.; Ohsuka, H.; Hino, T.; Kanamura, K., A Si-O-C Composite Anode: High Capability and Proposed Mechanism of Lithium Storage Associated with Microstructural Characteristics. ACS Appl. Mater. Interfaces 2010, 2, 998-1008. 
28. Shen, J.; Raj, R., Silicon-Oxycarbide Based Thin Film Anodes for Lithium Ion Batteries. J. Power Sources 2011, 196, 5945-5950.

29. Ahn, D.; Raj, R., Cyclic Stability and C-Rate Performance of Amorphous Silicon and Carbon Based Anodes for Electrochemical Storage of Lithium. J. Power Sources 2011, 196, 2179-2186.

30. Bhandavat, R.; Singh, G. Stable and Efficient Li-Ion Battery Anodes Prepared from Polymer-Derived Silicon Oxycarbide-Carbon Nanotube Shell/Core Composites. J. Phys. Chem. C 2013, 117, 11899-11905.

31. Ahn, D.; Raj, R., Thermodynamic Measurements Pertaining to the Hysteretic Intercalation of Lithium in Polymer-Derived Silicon Oxycarbide. J. Power Sources 2010, 195, 3900-3906.

32. Feng, Y., Electrochemical Properties of Heat-Treated Polymer-Derived SiCN Anode for Lithium Ion Batteries. Electrochim. Acta 2010, 55, 5860-5866.

33. Fukui, H.; Ohsuka, H.; Hino, T.; Kanamura, K., Polysilane/Acenaphthylene Blends Toward Si-O-C Composite Anodes for Rechargeable Lithium-Ion Batteries. J. Electrochem. Soc. 2011, 158, A550-A555.

34. Kaspar, J.; Graczyk-Zajac, M.; Riedel, R., Determination of the Chemical Diffusion Coefficient of Li-ions in Carbon-Rich Silicon Oxycarbide Anodes by Electro-Analytical Methods. Electrochim. Acta. 2014, 115, 665-670.

35. Liebau-Kunzmann, V.; Fasel, C.; Kolb, R.; Riedel, R., Lithium Containing Silazanes as Precursors for SiCN: Li Ceramics - A Potential Material for Electrochemical Applications. J. Eur. Ceram. Soc. 2006, 26, 3897-3901.

36. Su, D.; Li, Y. L.; Feng, Y.; Jin, J., Electrochemical Properties of Polymer-Derived SiCN Materials as the Anode in Lithium Ion Batteries. J. Am. Ceram. Soc. 2009, 92, 29622968.

37. Graczyk-Zajac, M.; Mera, G.; Kaspar, J.; Riedel, R., Electrochemical Studies of CarbonRich Polymer-Derived SiCN Ceramics as Anode Materials for Lithium-Ion Batteries. J. Eur. Ceram. Soc. 2010, 30, 3235-3243.

38. Kaspar, J.; Mera, G.; Nowak, A. P.; Graczyk-Zajac, M.; Riedel, R., Electrochemical Study of Lithium Insertion into Carbon-Rich Polymer-Derived Silicon Carbonitride Ceramics. Electrochim. Acta 2010, 56, 174-182. 
39. Tamai, H.; Sugahara, H.; Yasuda, H., Preparation of Carbons from Pitch Containing Polysilane and their Anode Properties for Lithium-Ion Batteries. J. Mater. Sci. Lett. 2000, 19, 53-56.

40. Bhandavat, R.; Singh, G., Synthesis, Characterization, and High Temperature Stability of Si(B)CN-Coated Carbon Nanotubes Using a Boron-Modified Poly(ureamethylvinyl)Silazane Chemistry. J. Am. Ceram. Soc. 2012, 95, 1536-1543.

41. Sarkar, S.; Gan, Z.; An, L.; Zhai, L., Structural Evolution of Polymer-Derived Amorphous SiBCN Ceramics at High Temperature. J. Phys. Chem. C 2011, 115, 2499325000.

42. Hermann, A. M.; Wang, Y. T.; Ramakrishnan, P. A.; Balzar, D.; An, L. N.; Haluschka, C.; Riedel, R., Structure and Electronic Transport Properties of Si-(B)-C-N Ceramics. J. Am. Ceram. Soc. 2001, 84, 2260-2264.

43. Riedel, R.; Kienzle, A.; Dressler, W.; Ruwisch, L.; Bill, J.; Aldinger, F., A Silicoboron Carbonitride Ceramic Stable to 2,000 Degrees C. Nature 1996, 382, 796-798.

44. David, L.; Asok, D.; Singh, G., Synthesis and Extreme Rate Capability of Si-Al-C-N Functionalized Carbon Nanotube Spray-on Coatings as Li-Ion Battery Electrode. ACS Appl. Mater. Interfaces. 2014, 6, 16056-16064.

45. Zimmermann, A.; Bauer, A.; Christ, M.; Cai, Y.; Aldinger, F., High-Temperature Deformation of Amorphous Si-C-N and Si-B-C-N Ceramics Derived from Polymers. Acta Mater. 2002, 50, 1187-1196.

46. Ramakrishnan, P. A.; Wang, Y. T.; Balzar, D.; An, L. A.; Haluschka, C.; Riedel, R.; Hermann, A. M., Silicoboron-Carbonitride Ceramics: A Class of High-Temperature, Dopable Electronic Materials. App. Phys. Lett. 2001, 78, 3076-3078.

47. Bhandavat, R.; Singh, G., Improved Electrochemical Capacity of Precursor-Derived $\mathrm{Si}(\mathrm{B}) \mathrm{CN}-\mathrm{Carbon}$ Nanotube Composite as Li-Ion Battery Anode. ACS Appl. Mater. Interfaces 2012, 4, 5092-5097.

48. Feng, Y.; Du, G. X.; Zhao, X. J.; Yang, E. C., Preparation and Electrochemical Performance of SiCN-CNTs Composite Anode Material for Lithium Ion Batteries. $J$ Appl. Electrochem. 2011, 41, 999-1002. 
49. Graczyk-Zajac, M.; Fasel, C.; Riedel, R., Polymer-Derived-SiCN Ceramic/Graphite Composite as Anode Material with Enhanced Rate Capability for Lithium Ion Batteries. J. Power Sources 2011, 196, 6412-6418.

50. Kolb, R.; Fasel, C.; Liebau-Kunzmann, V.; Riedel, R., SiCN/C-Ceramic Composite as Anode Material for Lithium Ion Batteries. J. Eur. Ceram. Soc. 2006, 26, 3903-3908.

51. Bechelany, M.; Bernard, S.; Brioude, A.; Cornu, D.; Stadelmann, P.; Charcosset, C.; Fiaty, K.; Miele, P., Synthesis of Boron Nitride Nanotubes by a Template-Assisted Polymer Thermolysis Process. J. Phys. Chem. C 2007, 111, 13378-13384.

52. Salles, V.; Bernard, S.; Li, J.; Brioude, A.; Chehaidi, S.; Foucaud, S.; Miele, P., Design of Highly Dense Boron Nitride by the Combination of Spray-Pyrolysis of Borazine and Additive-Free Sintering of Derived Ultrafine Powders. Chem. Mater. 2009, 21, 29202929.

53. Termoss, H.; Toury, B.; Pavan, S.; Brioude, A.; Bernard, S.; Cornu, D.; Valette, S.; Benayoun, S.; Miele, P., Preparation of Boron Nitride-Based Coatings on Metallic Substrates Via Infrared Irradiation of Dip-Coated Polyborazylene. J. Mater. Chem. 2009, 19, 2671-2674.

54. Li, J.; Bernard, S.; Salles, V.; Gervais, C.; Miele, P., Preparation of PolyborazyleneDerived Bulk Boron Nitride with Tunable Properties by Warm-Pressing and Pressureless Pyrolysis. Chem. Mater. 2010, 22, 2010-2019.

55. Alauzun, J. G.; Ungureanu, S.; Brun, N.; Bernard, S.; Miele, P.; Backov, R.; Sanchez, C., Novel Monolith-Type Boron Nitride Hierarchical Foams Obtained Through Integrative Chemistry. J. Mater. Chem. 2011, 21, 14025-14030.

56. Schlienger, S.; Alauzun, J.; Michaux, F.; Vidal, L.; Parmentier, J.; Gervais, C.; Babonneau, F.; Bernard, S.; Miele, P.; Parra, J. B., Micro-, Mesoporous Boron NitrideBased Materials Templated from Zeolites. Chem. Mater. 2012, 24, 88-96

57. Zhong, W.; Wang, S.; Li, J.; Bechelany, M. C.; Ghisleni, R.; Rossignol, F.; Balan, C.; Chartier, T.; Bernard, S.; Miele, P., Design of Carbon Fiber Reinforced Boron Nitride Matrix Composites by Vacuum-Assisted Polyborazylene Transfer Molding and Pyrolysis. J. Eur. Ceram. Soc. 2013, 33, 2979-2992.

58. Hummers, W. S.; Offeman, R. E., Preparation of Graphitic Oxide. J. Am. Chem. Soc. 1958, 80, 1339-1339. 
59. Li, Y. L.; Kroke, E.; Riedel, R.; Fasel, C.; Gervais, C.; Babonneau, F., Thermal CrossLinking and Pyrolytic Conversion of Poly(Ureamethylvinyl)Silazanes to Silicon-Based Ceramics. App. Organomet. Chem. 2001, 15, 820-832.

60. Antsiferov, V. N.; Gilyov, V. G.; Karmanov, V. I., IR-Spectra and Phases Structure of Sialons. Vib. Spectro. 2002, 30, 169-173.

61. Wada, N.; Solin, S. A.; Wong, J.; Prochazka, S., Raman and Ir Absorption Spectroscopic Studies on Alpha, Beta, and Amorphous $\mathrm{Si}_{3} \mathrm{~N}_{4}$. J. Non-Crystalline Solids 1981, 43, 7-15.

62. Ermer, E.; Ptak, W. S., FTIR Studies of Structural Effects due to Boron Addition in Sintered Silicon Carbide. Vib. Spectro. 2002, 29, 211-215.

63. Lv, Q.; Cao, C. B.; Li, C.; Zhang, J. T.; Zhu, H. X.; Kong, X.; Duan, X. F., Formation of Crystalline Carbon Nitride Powder by a Mild Solvothermal Method.J. Mater. Chem. 2003, 13, 1241-1243.

64. Brun, N.; Janot, R.; Sanchez, C.; Deleuze, H.; Gervais, C.; Morcrette, M.; Backov, R., Preparation of $\mathrm{LiBH}_{4} @$ carbon Micro-Macrocellular Foams: Tuning Hydrogen Release Through Varying Microporosity. Energy Environ. Sci. 2010, 3, 824-830.

65. Wang, C.; Li, D.; Too, C. O.; Wallace, G. G. Electrochemical Properties of Graphene Paper Electrodes Used in Lithium Batteries. Chem. Mater. 2009, 21, 2604.

66. David, L.; Singh, G. Reduced Graphene Oxide Paper Electrode: Opposing Effect of Thermal Annealing on Li and Na Cyclability. J. Phys. Chem. C 2014, 118, 28401-28408.

67. Yu, P.; Popov, B. N.; Ritter, J. A.; White, R. E. Determination of the Lithium Ion Diffusion Coefficient in Graphite. J. Electrochem. Soc. 1999, 146, 8-14.

68. Persson, K.; Sethuraman, V. A.; Hardwick, L. J.; Hinuma, Y.; Meng, Y. S.; Ven, A.; Srinivasan, V.; Kostecki, R.; Ceder, G. Lithium Diffusion in Graphitic Carbon. J. Phys. Chem. Lett. 2010, 1, 1176-1180. 


\section{FIGURES}

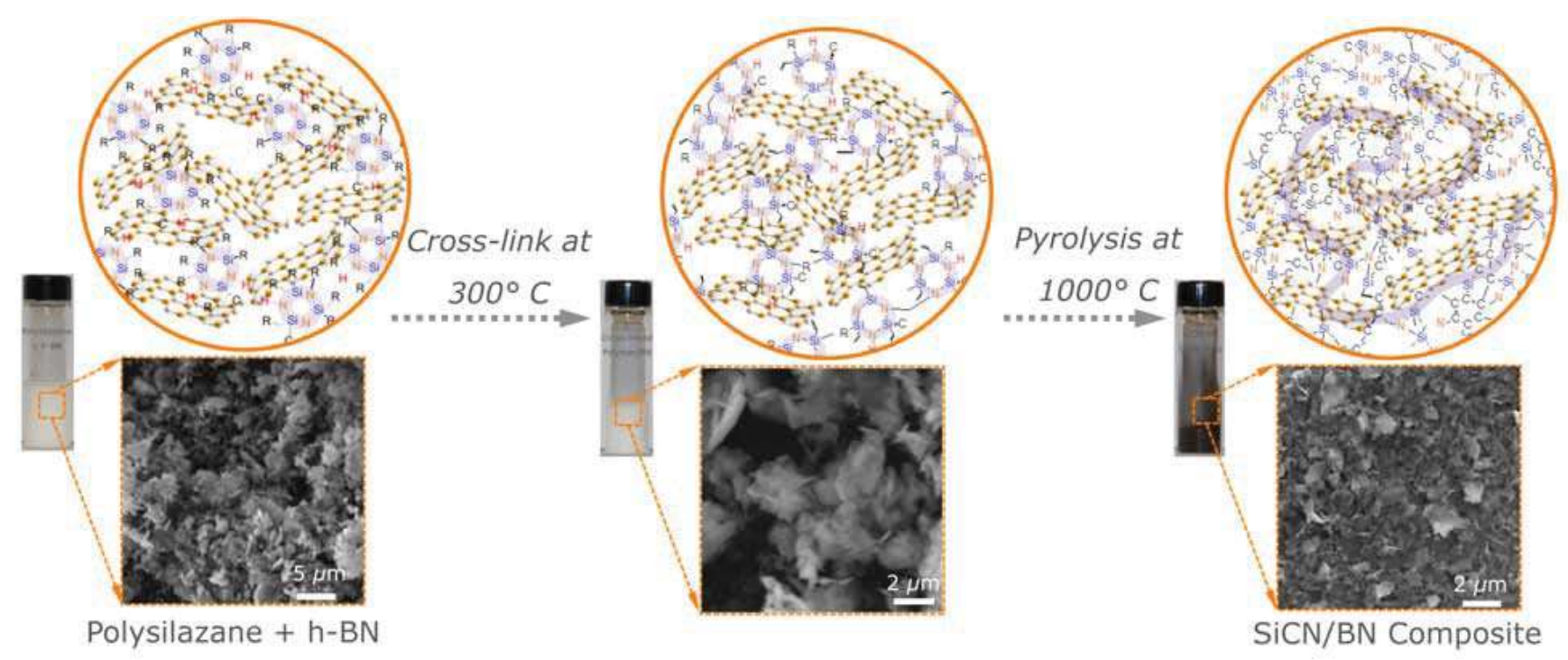

FIGURE 1. Schematic showing polymer to ceramic conversion and simultaneous incorporation of $\mathrm{BN}$ sheets in $\mathrm{SiCN}$ matrix. ( $\mathrm{L}$ to $\mathrm{R}$ ): polysilazane precursor uniformly wets $\mathrm{BN}$ sheets when they are stirred together. As the mixture is heated in flowing $\mathrm{N}_{2}$, polysilazane cross-links at approximately $300{ }^{\circ} \mathrm{C}$ to form long chains connected by BN sheets. Further pyrolysis at $1000{ }^{\circ} \mathrm{C}$ forms BN sheets embedded with SiCN ceramic matrix. Inset shows SEM images of composite at various stages of processing. 


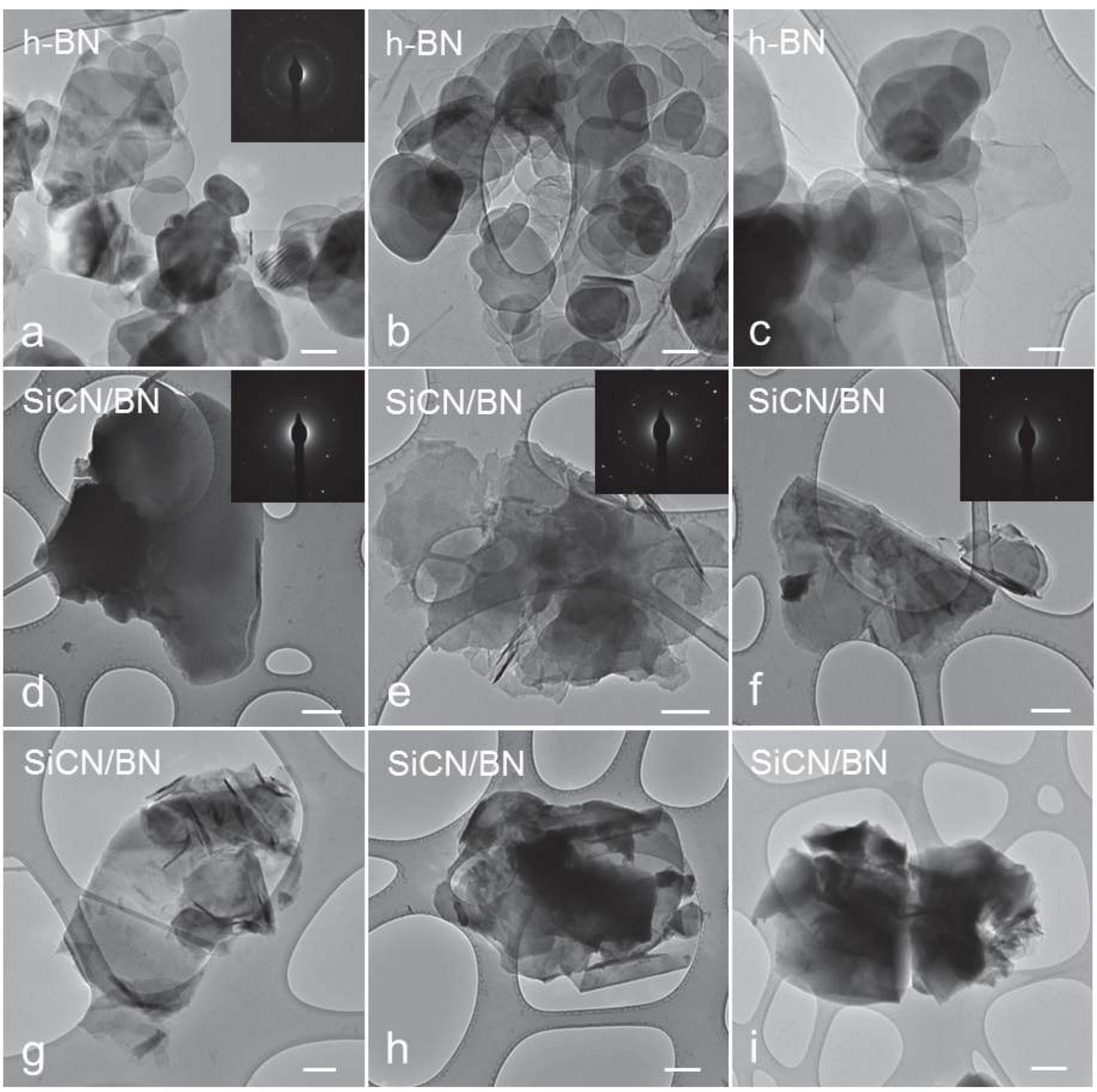

FIGURE 2. (a through c): TEM images of as-obtained BN sheets, (d through i): as-synthesized $\mathrm{SiCN} / \mathrm{BN}$ composite material. The insets show the SAED pattern obtained for the corresponding TEM image. SiCN/BN showed distinct pattern corresponding to BN. Scale bar is $50 \mathrm{~nm}$. 

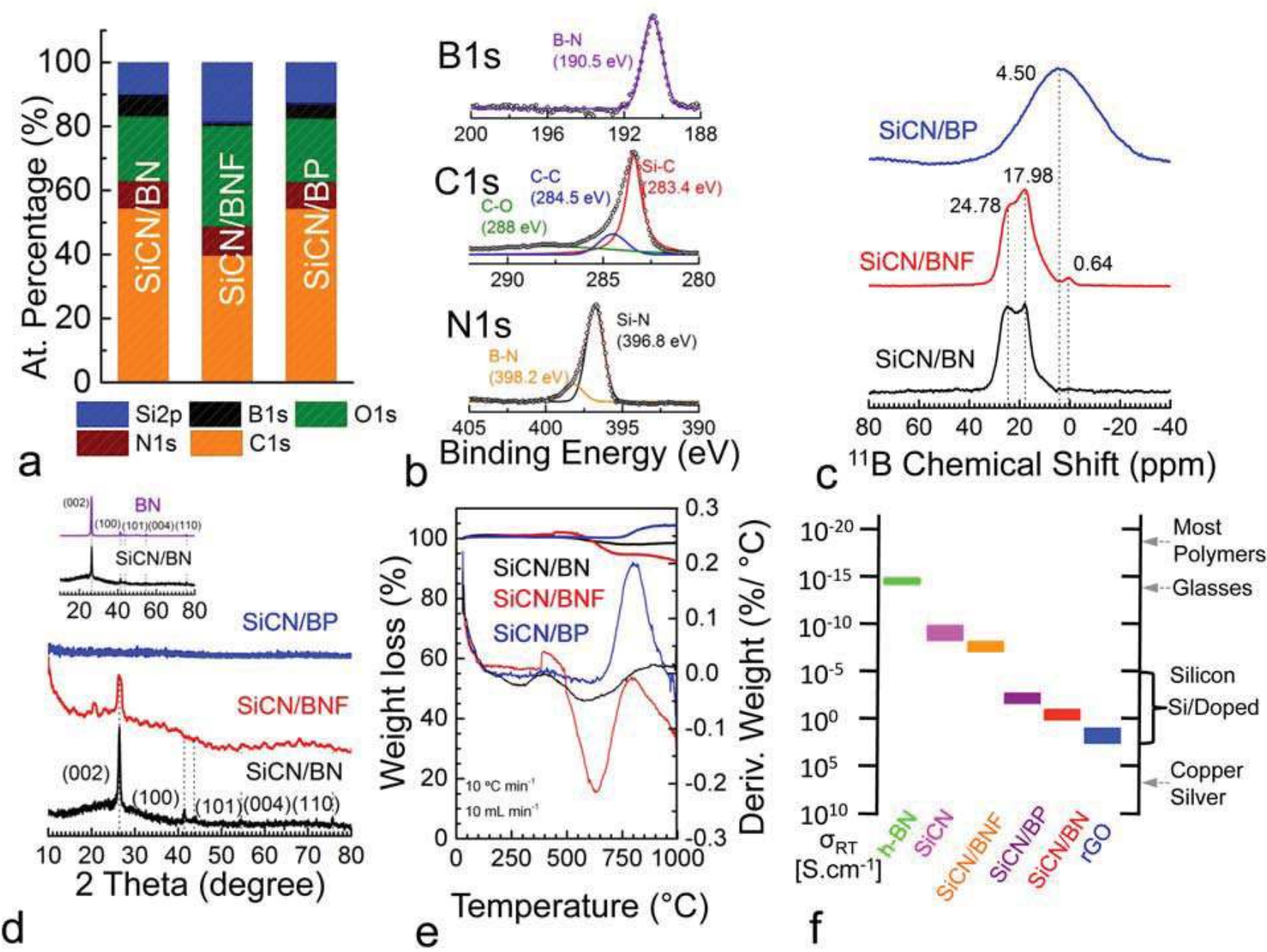

FIGURE 3. (a) Bar chart of atomic percentage of elements present in SiCN/BN, SiCN/BNF and SiCN/BP composites obtained using XPS. (b) High-resolution XPS of B 1s, C 1s and N 1s peaks in $\mathrm{SiCN} / \mathrm{BN}$ composites. (c) ${ }^{11} \mathrm{~B}$ NMR spectra showing $\mathrm{B}-\mathrm{N}$ bonds in planar $\mathrm{BN}_{3}$ groups in case of $\mathrm{SiCN} / \mathrm{BN}$ and $\mathrm{SiCN} / \mathrm{BNF}$ and amorphous boron in SiCN/BP ceramic composites. (d) XRD comparison $\mathrm{SiCN} / \mathrm{BN}, \mathrm{SiCN} / \mathrm{BNF}$ and $\mathrm{SiCN} / \mathrm{BP}$ composites. Inset shows X-ray comparison of 'as-obtained' BN powder and SiCN/BN composite. Characteristic BN peaks were clearly observed in SiCN/BN composite. (e) Thermogravimetric analysis plots of three composites proving SiCN/BN's high thermal stability and oxidation resistance. (f) Electrical conductivity comparison of various SiCN PDCs specimen prepared in this study. rGO and BN are included to demonstrate the wide range in conductivity that can be achieved in these ceramics. 

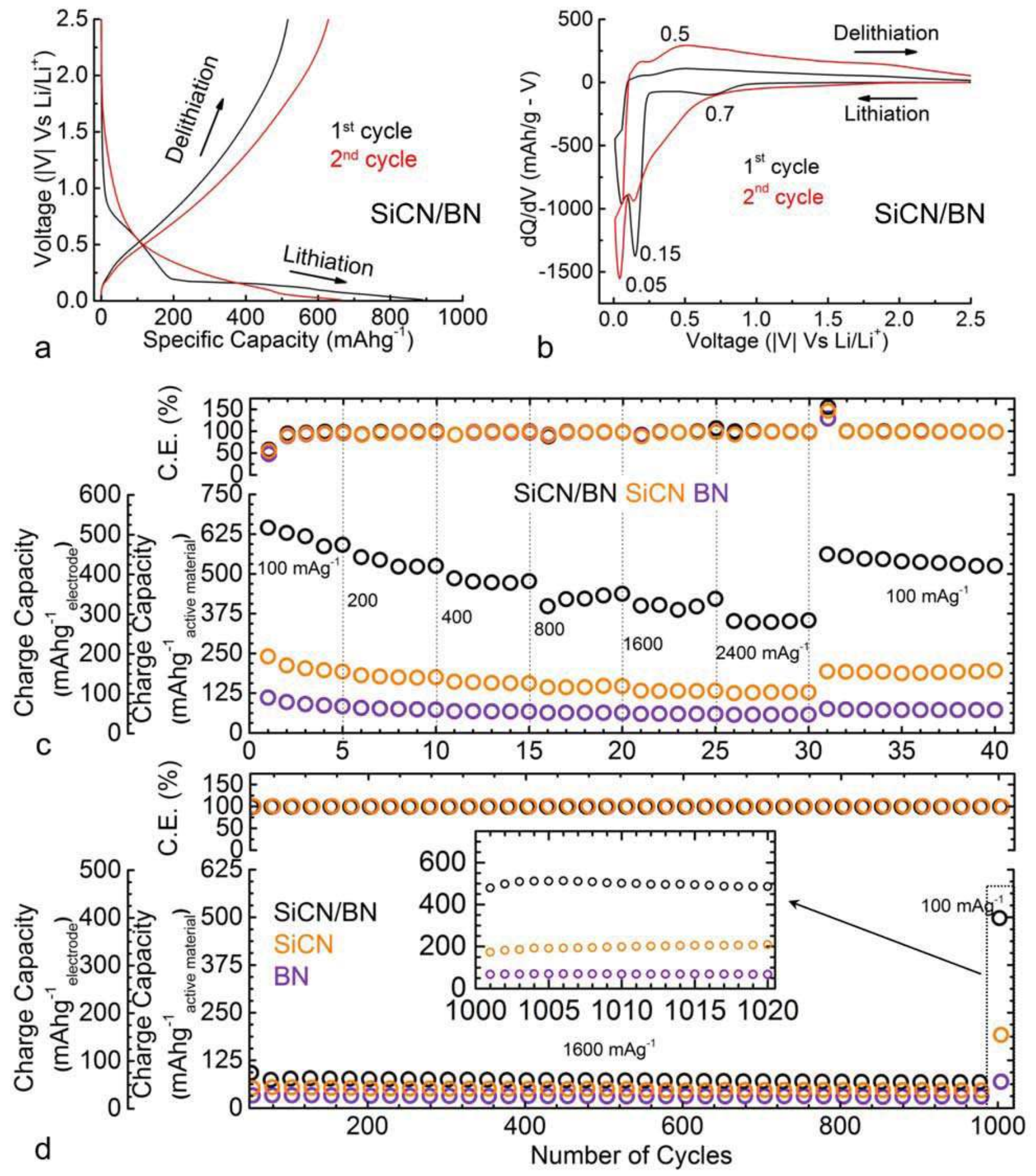

FIGURE 4. $1^{\text {st }}$ and $2^{\text {nd }}$ cycle (a) voltage profile and (b) differential capacity curve of $\mathrm{SiCN} / \mathrm{BN} / \mathrm{rGO}$. (c) Charge capacity of $\mathrm{SiCN} / \mathrm{BN} / \mathrm{rGO}$ with $\mathrm{BN} / \mathrm{rGO}$ and $\mathrm{SiCN} / \mathrm{rGO}$ for comparison. Cells were cycled asymmetrically at increasing rates for every five cycles. (d) 
Charge capacity when symmetrically at $1600 \mathrm{~mA} \mathrm{~g}^{-1}$ for 1000 cycles and return to $100 \mathrm{~mA} \mathrm{~g}^{-1}$. Charge capacity of SiCN/BN was more than twice than the capacity of SiCN.

TABLE 1 Summary of electrochemical cycling data for various electrodes used in this study and comparison with data from literature. NOTE: All electrodes in the present study were prepared with approximately $20 \mathrm{wt} \% \mathrm{rGO}$. Capacity values are with respect to total electrode weight.

\begin{tabular}{|c|c|c|c|c|}
\hline Electrode material & $\begin{array}{c}1^{\text {st }} \text { Cycle } \\
\text { charge, }\end{array}$ & $\begin{array}{c}\text { Capacity at } \\
\text { max. current } \\
\text { density tested, } \\
\text { mAh g }\end{array}$ & $\begin{array}{c}\text { Max. } \\
\text { number of } \\
\text { cycles tested }\end{array}$ & $\begin{array}{c}\text { Charge } \\
\text { capacity after } \\
1000 \text { cycles at } \\
100 \text { mA g }^{-1}\end{array}$ \\
\hline SiCN/BN & $475 \pm 42 *$ & $283.2(2400)$ & 1020 & 400.8 \\
\hline $\mathrm{SiCN} / \mathrm{BNF}$ & 262.4 & $100.8(2400)$ & 1020 & 202.4 \\
\hline $\mathrm{SiCN} / \mathrm{BP}$ & 140 & $68.8(2400)$ & 1020 & 95.2 \\
\hline $\mathrm{SiCN}$ & 192 & $102.3(2400)$ & 1020 & 159.2 \\
\hline $\mathrm{BN}$ & 88.8 & $46.4(2400)$ & 1020 & 55.2 \\
\hline $\mathrm{BP}$ & 99.2 & $55.2(2400)$ & 1020 & 68 \\
\hline $\mathrm{SiCN}-1000{ }^{\circ} \mathrm{C}^{36}$ & 456 & $171(100)$ & 30 & - \\
\hline $\mathrm{SiCN}-1100{ }^{\circ} \mathrm{C}^{37}$ & 263 & $100(36)$ & 50 & - \\
\hline $\mathrm{SiCN}-1300{ }^{\circ} \mathrm{C}^{3} \mathrm{O}_{2}{ }^{37}$ & 291 & $250(72)$ & 60 & - \\
\hline $\mathrm{SiCN}-1100{ }^{\circ} \mathrm{C}^{38}$ & 254 & $95(360)$ & 10 & - \\
\hline $\mathrm{Si}(\mathrm{B}) \mathrm{CN}-\mathrm{CNT}^{47}$ & 362 & $430(100)$ & 30 & - \\
\hline $\mathrm{SiCN}-\mathrm{Graphene}{ }^{49}$ & 420 & $440(40)$ & 50 & - \\
\hline $\mathrm{Graphite}{ }^{65}$ & 298 & $240(50)$ & 50 & - \\
\hline $\mathrm{rGO}-500{ }^{\circ} \mathrm{C}^{66}$ & 292 & $180(2400)$ & 1020 & 190 \\
\hline
\end{tabular}

* Average of three samples. Refer supporting Information Figure S11 


\section{TOC GRAPHICS}

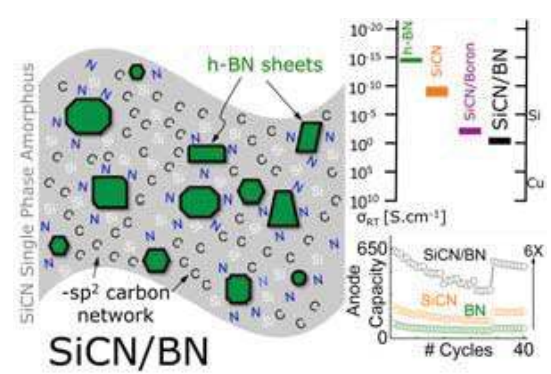

